\title{
THE NAHDLATUL ULAMA Its Early History and Contribution to the Establishment of Indonesian State
}

\author{
Faisal Ismail \\ UIN Sunan Kalijaga, Yogyakarta - Indonesia
}

\begin{abstract}
Established on 31 January 1926 in Surabaya, East Java, by some prominent kyais like K.H. Abdul Wahab Hasbullah and K.H. Hasyim Asy'ari, the Nahdlatul Ulama was born in the culture of pesantren where 'traditional Islam' has been rooted and preserved. In this context, the Nahdlatul Ulama declared its religious ideology as 'ahl al-sunnah wa al-jamā'ah.' This religious ideology has become important characteristics of the Nahdlatul Ulama that differentiate itself from Muslim 'modernist' organizations. In its early movements, the Nahdlatul Ulama plyed a pivotal role by, for example, banning the Muslim youths from entering the Dutch military service, prohibiting the Muslims from supporting the Dutch army, and rejecting the Dutch aid which was offered to the Nahdlatul Ulama's madrasas. Furthermore, together with other nationalist movements, the Nahdlatul Ulama actively took part in the process of establishing the Indonesian State and in the war to defend the Indonesian independence against the Dutch who tried to re-establish their colonial rule in Indonesia. These facts, undoubtedly, proved that the Nahdlatul Ulama made a great contribution to the nation and state of Indonesia.
\end{abstract}

Keywords: Nahdlatul Ulama', the Dutch, Indonesia, 'ulamā', pesantren.

\section{Introduction}

The history of the NU (Nahdlatul Ulama, or Renaissance of the 'Ulamā') can be divided into five periods. The first period lasted from 1926 until 1945 during which the NU existed as a socio-religious organization. The second period lasted from 1945 until 1952 during 
which the NU joined a federative political organization called the Masyumi (Majelis Syuro Muslimin Indonesia, or Indonesian Muslim Consultative Council) as the only Islamic political party, which was expected to accommodate Islamic political aspirations in Indonesia. From 1952 until 1973, the NU entered its third period and served as an independent political party, which was totally separate from the Masyumi. The fourth period lasted from 1973 until 1984 during which the NU fused itself into the PPP (Partai Persatuan Pembangunan, or United Development Party). From 1984 until now the NU has entered its fifth historical period and has returned to its original purpose as a socio-religious organization. ${ }^{1}$

This study will deal mostly with the early history or the first period of the NU and the beginning of its second period, describing the main factors which motivated its founding fathers to establish this organization, the position of the 'ulama' in the NU, and its activities and movements during the Dutch and Japanese occupation until the achievement of the Indonesian independence. This study will examine the important role and strategic movements of the NU during the Dutch colonial rule, the Japanese occupation and the independence war. Despite the fact that the NU at that time was purely a socioreligious organization, it actively and significantly played a pivotal role in opposing Dutch colonial rule in Indonesia. Also, this study will discuss the important role and significant contribution of the NU to the process of the establishment of the Indonesian State and its role in the war to defend Indonesian independece against the Dutch who tried to re-establish colonial rule in Indonesia.

\footnotetext{
1 K.H. Saifuddin Zuhri, Sejarah Kebangkitan Islam dan Perkembangannya di Indonesia (Bandung: PT Al-Ma'arif, 1981), p. 623. Until the 1982 Indonesian General Election, the Nahdlatul Ulama continued to vote for the PPP. Some months before the 1987 Indonesian General Election, however, the Executive Council of the Nahdlatul Ulama declared that its members were free to vote for either the Golkar (Golongan Karya, or Functional Group), the PDI (Partai Demokrasi Indonesia, or Indonesian Democratic Party) or the PPP itself. Consequently, the PPP lost a large number of its supporters in comparison to the 1982 Indonesian General Election. The Nahdlatul Ulama withdrew its support from the PPP because of internal conflicts among the leaders of the PPP, which was a fusion of four Islamic parties, i.e., the NU, the Parmusi (Partai Muslimin Indonesia, or Indonesian Muslim Party), the PSII (Partai Sarekat Islam Indonesia, or Indonesian Islamic Union Party), and the Perti (Persatuan Tarbiyah Islamiyah, or Association of Islamic Education).
} 
The NU follows the ideology of traditional Islam, that is, Islam which has continued to adhere to the thoughts and opinions of the 'ulamä' regarding the concepts of Islamic law, tafsir (exegesis of the Qur'an), and kalam (Islamic theology) which were developed from the seventh century until the thirteenth century. The NU declares that its religious ideology is abl al-ssunnah wa al-jamá ah. What is actually meant by abl al-ssunnah wa al-jama'ab in the view of the NU will also be discussed in this study. But before we discuss the important topics above, it is necessary to talk about the conditions, especilly in Java, prior to the establishment of the NU so that we can understand the historical context, cultural setting and socio-religious backgrouns in wihich the NU was born.

\section{Situation before the Birth of the NU}

"Go back to the Qur'an and Hadith!" This was an important and widespread slogan voiced by the modernist Muslims in Indonesia, especially in Java and West Sumatera, at the beginning of the twentieth century. Their strong appeal to go back to the Qur'an and Hadith, that is, to return to Islamic purity, was welcomed enthusiastically by their supporters. Along with voicing that slogan, they attacked and condemned some religious practices of traditionalist Muslims, such as qunut, ${ }^{2}$ tawassu ${ }^{3}$ and tarekat (tariqah). The Muslim modernists rejected those kinds of religious practices and regarded some of them as bid'ah (religious innovation), which had to be abandoned.

In contrast, the traditionalist Muslims argued that those religious practices they performed were not bid'a and not contrary to the teachings of Islam. Consequently, religious disputes occurred between the two groups, which consumed a great deal of energy, and time in arguing with one another. The religious disputes between the modernists and the traditionalists dealt in fact with furü (detail, branch) questions and not with usül (root, principle) questions. However, as Clifford Geertz said, the conflict between the two groups "was indeed a sharp and bitter one." 4 As a result, this conflict led to an unharmo-

\footnotetext{
2 Qunut is a special reading recited by traditionalist Muslims during the second part (rakea'a) of the morning prayer.

3 Tawassul is a practice in which the member of the tarekat recalls his teachers before he begins his dhikr.

${ }^{4}$ Clifford Geertz, The Religion of Java (Chicago: The University of Chicago Press, 1976), p. 130.
} 
nious relationship, characterized by tension and disunity between the two groups.

There is no doubt that the modernist Muslims derived their inspiration and influence primarily from Wahhābism and the ideas of reform of Muhammad 'Abduh (1849-1905) and Jamāl al-Dīn al-Afghäni (1839-1897). As we know, the Wahhäbi movement began formally in 1747 after its founder, Muhammad bin 'Abd al-Wahhāb (d. 1792), had visited many Islamic countries and came to realize that religious innovation had obtained currency and that superstitious uses had spread and were indistinguishable from idolatry. Upon returning to his homeland in Central Arabia, Muhammad bin 'Abd al-Wahhāb and his followers therefore began a campaign of religious purification. ${ }^{5}$

The Wahhābi teaching was formally accepted by the Saudis. According to 'Uthmān bin Bishr, in their zeal to rid Islam of its cult of saints and other innovations they sacked Karbala in 1801, captured Makkah in 1803 and Medina the following year, destroyed tombs and purged these cities of all semblances of idolatry. ${ }^{6}$ When Karbala was attacked, a considerable Saudi force massacred some five thousand Shi' ${ }^{\top}$ is, demolished the domes of various tombs-including that of the Prophet's grandson, Husayn-and plundered the whole city. ${ }^{7}$ Wahhābism continued to flourish when 'Abd al-'Aziz bin Sa'ūd came to power in Makkah after his defeat of Sharif Husayn in 1925. Muhammad ibn 'Abd al-Wahhāb was regarded as a reformer not in the sense that "he desired a change in the doctrines of Islam or even a new interpretation of its tenets, but in the sense that he felt it his mission to denounce innovations and accretions, and preach a return to Islam's former purity."

According to H.A.R. Gibb, a well-known Western scholar, the reformist ideas of Muhammad 'Abduh can be summarized as a call for: (1) The purification of Islam from corrupting influences and practices; (2) The reformation of Muslim higher education; (3) The

\footnotetext{
5 George Antonious, The Arab Awakening: The Story of the Arab National Movement (Beirut: Librairie Du Liban 1969), p. 22.

6 Uthman ibn Bishr, quoted in Philip K. Hitti, History of the Arabs (London: The Macmillan Press, Ltd., 1980), pp. 740-741.

${ }^{7}$ John B. Philby, quoted in Juan R.I. Cole and Nikki R. Keddie (eds.), Shiism and Social Protest (New Haven: Yale University Press 1986), p. 232.

${ }^{8}$ Antonious, The Arab Awakening, p. 22.
} 
reformulation of Islamic doctrine in the light of modern thought; (4) The defense of Islam against European influences and Christian attacks. ${ }^{9}$

In spreading his idea of reform, Muhammad 'Abduh collaborated with his teacher, Jamā al-Dīn Al-Afghānì was actually regarded as being the first to voice the need for Islamic political reform in the Muslim world. His political project focused on pan-Islamism "as the only effective bulwark against foreign encroachments and domination of Muslim lands." 10 "Abduh and Afghāni published a weekly newspaper called al-Urwa al-Wuthqa (The Indissoluble Link) during their stay in Paris at the beginning of 1884. Through this newspaper, they preached the ideas of reform which had far-reaching effects on the minds of Muslims everywhere. "It imbued them with the desire for freedom, and inspired them with patriotism, reviving their will to fight their oppressors and strengthening the quality of their moral fibre."11 Philip K. Hitti said that "more than any other modern writers, these two contributed to the breaking of the scholastic shell which encased Islam since medieval Islam."12

The two important factors above, puritanical Wahhābism and Islamic reformism, gave impetus to the emergence of the modernist movements in Indonesia, particularly in West Sumatera and Java. In West Sumatera, Islamic reform took place in Minangkabau. Around 1800, a number of hajjis, including Haji Miskin, returned from Makkah "under the influence of Wahhäbite fundamentalism, and called for a return to Islamic purity." 13 Their movement, known as the Padri Movement, grew steadily in the first two decades of the nineteenth century and stimulated a reaction from the established leaders of Minangkabau, the adat (local tradition) chiefs.

In order to put their ideas into practice, the Padris used violent means, expelling or killing adat chiefs and others who opposed them. ${ }^{14}$

\footnotetext{
${ }^{9}$ H.A.R. Gibb, Modern Trends in Islam (New York: Octagon Books,1981), p. 33.

${ }^{10}$ Fazlur Rahman, Islam (Chicago: The University of Chicago Press, 1979), p. 226.

11 Osman Amin, Muhammad Abduh, trans. Charles Wendell (Washington: American Council of Learned Societies, 1953), p. 55.

12 Hitti, History, p. 754.

${ }^{13}$ David Joel Steinberg (ed.), In Search of Southeast Asia: A Modern History (Honolulu: University of Hawaii Press, 1985), p. 144.

14 William R. Roff, "Southeast Asian Islam in the Nineteenth Century," in P.M. Holt et
} 
The conflict between the Padri and the adat chiefs resulted in the outbreak of the Padri War. The Dutch interfered in this conflict, taking the side of the adat chiefs with the ultimate aim of establishing their power in that area. According to Taufik Abdullah, the Padri War was actually a war between the followers of Wahhäbism, on the one hand, and their brothers in Islam on the other, whose advocacy of adat was considered contrary to pure Islam. Some others called it the war between the Kaum Muda (Young Group) and the Kaum Tua (Old Group). ${ }^{15}$

It was Tahir Jalaluddin who also advocated Islamic reform in West Sumatera after his return from studying in MakkahMakkah and Cairo around 1882. Jalaluddin's movement was continued by his disciples, such as Muhammad Jamil Jambek, Abdullah Ahmad, and Abdul Karim Amrullah. With a strong sense of purpose, they introduced the ideas of Ibn Taymiyah, Ibn al-Qayyim, Muhammad bin 'Abd al-Wahhāb, and Muhammad 'Abduh. In spreading their ideas of reform, they established, in early 1911, a journal called al-Munir (The Illuminative) which had a far-reaching influence not only in Sumatera but in Java as well. ${ }^{16}$ These reformist Muslims condemned a variety of religious practices that they regarded as innovations, and their condemnation stimulated a reaction from the Kaum Tua Muslims, such as Sayyid Zaini Dahlan and Shaykh Nabhani. Debates and disputes between the two groups concerning some controversial religious practices, such as tawassul and its like, occurred and this led them to denounce each other. ${ }^{17}$

In Java, Islamic reform was pioneered by K.H. Ahmad Dahlan (1868-1923), a Muslim leader who lived in Yogyakarta, Central Java. He studied Islam in Makkah for some years and became familiar with the ideas of Ibn Taymiyah, al-Ghazāil, Muhammad bin 'Abd alWahhāb, al-Afghāni, and Muhammad 'Abduh. ${ }^{18}$ He began to introduce

al (eds.), The Cambridge History of Islam, vol. 2 A (Cambridge: Cambridge University Press, 1987), p. 166.

15 Taufik Abdullah, Islam di Indonesia (Jakarta: Tintamas, 1974), p. 61.

${ }^{16}$ Harry J. Benda, "Southeast Asian Islam in the Twentieth Century," in P.M. Holt et al (eds.), The Cambridge History of Islam vol. 2 A (Cambridge: Cambridge University Press, 1987), p. 189.

${ }^{17}$ Hamka, Pengaruh Mohammad Abduh di Indonesia (Jakarta: Tintamas, 1961), pp. 16-17.

${ }^{18}$ Junus Salam, Riwayat Hidup K. H. A. Dablan: Amal dan Perjuangannya (Jakarta: Depot 
his ideas of reform in 1905, and he eventually founded a modern Islamic organization called the Muhammadiyah in Yogyakarta on November 18, 1912. The Muhammadiyah, as a socio-religious organization, carried on much of its work through auxiliary organizations such as youth and women's associations, clinics, orphanages, and above all, a large school system which presented academic subjects and taught Islam not merely by recital and exegesis but also as a basic system of religious, ethical, and social belief. ${ }^{19}$ The other organizations established by the modernist Muslims were the Sarekat Islam (Islamic Union), al-Irsyad (Guidance), and the Persatuan Islam (Islamic Association). The Sarekat Islam was a transformation of the Sarekat Dagang Islam (Union of Islamic Commerce), founded by $\mathrm{H}$. Samanhudi in Surakarta, Central Java, on November 11, 1906. The two outstanding figures of the Sarekat Islam were H.O.S. Tjokroaminoto (1883-1934) and H. Agus Salim (1884-1954), both of whom received Dutch education.

Since the Sarekat Islam was much influenced by Afghânî's political ideas and movements, it was therefore concerned with political affairs and tried to remain distant from religious controversies. As for alIrsyad, it was an Arab organization established by Ahmad Soorkati in 1913. The Persatuan Islam was founded by a group of modernist Muslims in 1923 in Bandung, West Java, where Ahmad Hassan joined it and then contributed greatly to the development and progress of this organization. As mentioned above, the modernist Muslim attacks against some religious practices of the traditionalist Muslims were sharp and bitter. The Muhammadiyah, for example, strongly rejected the tarekat or șuffi practice of dhiker (remembering God by reciting His Names repeatedly). For the Muhammadiyah, sufism means

... to clean the heart and spirit of mankind from all uncleannesses, meanness and faults brought into being by lust of the lower nature, by Satan. It should be not another worldly experience achieved by magical practices but a practical and measurable influence for the good in human relations. It should assist Muslims to live more intelligent, refined and useful religious lives. On the other hand, for mysticism of a kind which rejects all worldly things, leads to mere asceticism, and gives itself up to the

Pengajaran Muhammadiyah, 1968), p. 8.

${ }^{19}$ Steinberg (ed.), Southeast Asia, p. 290. 
repetition of the dhikr, there is no room in the Muhammadiyah. ${ }^{20}$

The Persatuan Islam's attack was even more hostile when it accused the traditionalist Muslims of committing a sin because they followed books written by the 'ulamā'. Referring to the Qur'anic verse (111: 103) which runs, "And hold fast, all of you together, to the cable of Allah, and do not separate," the Persatuan Islam vowed that "it would not rely on books written by Man."21 Moreover, the Persatuan Islam continued, "Those who rely on the books of the 'ulama', have in fact left God aside. Those who violate the regulations of God, commit a sin. Therefore, those who blindly follow [taqtid] the 'ulamà', commit a sin." 22 Then the Persatuan Islam added,

Those who rely on the books of 'ulamâ' differ from each other. Those who have differed from each other committed something that God has prohibited. Those who neglect God's prohibitions commit a sin. Therefore, those who merely follow the opinion of others [taqlîd], commit a sin. ${ }^{23}$

To narrow the gulf between the reformists and the traditionalists, the Sarekat Islam took the initiative of holding the Islamic Congress. The Congress was the natural outgrowth of the ideas of the Sarekat Islam, which from the beginning had been concerned with political affairs and Muslim unity, and had set religious disputes aside. The first Islamic Congress was held in Cirebon, West Java, from October 3 until November 2, 1922, and was attended by delegates of both the modernist and traditionalist Muslims. K.H. Abdul Wahab Hasbullah and K.H. Asnawi represented the traditionalist Muslims. The Congress almost failed because the two groups could not avoid discussing their religious disputes. In this Congress, the Muhammadiyah denounced those who followed the madhâhib (schools of Islamic law) by saying that Muslims ought to close the books written by the 'ulama', and refer only to the Qur'an and Hadith. In contrast, K.H. Abdul Wahab Hasbullah argued that the books of 'ulamā' were still relevant to use as

\footnotetext{
${ }^{20}$ Raymond Le Roy Archer, quoted in Deliar Noer, The Modernist Muslim Movement in Indonesia 1900-1942 (Kuala Lumpur: Oxford University Press, 1973), p.100.

${ }^{21}$ Quoted in Noer, Modernist Muslim, p. 98.

22 Ibid., pp. 98-99.

${ }^{23}$ Ibid.
} 
tools in understanding Islamic law which had been derived by the 'ulamā' from the primary source, the Qur'an and Hadith. ${ }^{24}$

Despite their differences, the modernists and the traditionalists at the Congress reached an agreement that the basis of all religious teaching is the Qur'an and Hadith; that the four imams, founders of the madhahbib, had come to their respective religious judgments after a careful and complete study and investigation of the texts in the Qur'an and Hadith; that reference to the Qur'an and Hadith is very important for the explanation of the various disciplines of Islam, and for the study of religious books; and finally, that interpretation of the Qur'an should not be done arbitrarily, but rather, it requires the necessary tools: various kinds of knowledge. ${ }^{25}$

The next Islamic Congress was held in Surabaya, East Java, from December 24-26, 1924. The main topics discussed in this Congress were, among others, the problem of ijtihād (individual interpretation of the Qur'an and Hadith) and the teaching of the Muhammadiyah and al-Irsyad. Among the important decisions made in this Congress were that the Muhammadiyah and al-Irsyad were not synonymous with the Wahhäbis; that the two organizations were not considered to deviate from any of the madhahib and that those who applied tawassul were not regarded as kajair (unbelievers). ${ }^{26}$ After a long and bitter debate in the Congress, the reformist and the traditionalist Muslim leaders came to agree that the gate of ijtihâd was still open and that it could be practiced by those who knew Arabic and were knowledgeable about the texts of the Qur'an and Hadith, the ijmā' (consensus) of the 'ulamā', the hadith narrators and their stories; and the reasons for the revelation of Qur'anic verses and the existence of Hadith statements.

The following congresses were dominated by the modernist Muslims. However, the relationship among the modernists themselves deteriorated because of differences and disputes. This deterioration reached its climax when the Sarekat Islam took action by prohibiting its members from becoming Muhammadiyah members; if they chose to join the Muhammadiyah, they were required to quit the Sarekat

\footnotetext{
24 Slamet Effendy Yusuf et al, Dinamika Kaum Santri: Menelusuri Jejak dan Pergolakan Internal NU (Jakarta: CV Rajawali, 1983), p. 15.

25 See Noer, Modernist Muslim, pp. 227-228, and p. 44.

${ }^{26}$ Ibid., p. 47.
} 
Islam. ${ }^{27}$ Meanwhile, a dispute also occurred between the Sarekat Islam and the Persatuan Islam. The Sarekat Islam, which was concerned with politics and Muslim unity, insisted that religious disputes be stopped in the hope of creating Muslim unity. On the other hand, the Persatuan Islam persisted in continuing to discuss religious disputes as part of its reform movements.

In a further development, the Indonesian Muslim leaders succeeded in establishing a committee called the Komite Khilafat (Caliphate Committee) in Surabaya on October 4, 1924. The chairman of this Komite was Wondoamiseno of the Sarekat Islam and its vicechairman was K.H. Abdul Wahab Hasbullah of the traditionalists. The Komite Khilafat was founded as a response of the Indonesian Muslim leaders to the idea of the Egyptian government which planned to hold a congress on the caliphate in 1924 to establish a new caliphate. The idea of establishing a new caliphate was motivated by the fact that Turkey under Mustafa Kemal Attaturk had abolished the sultanate in 1922, and then the Turkish National Assembly abolished the caliphate in 1924, by which Turkey aimed to become a modern secular state. 28

But the Congress on the caliphate scheduled to be held in Cairo was postponed. Consequently, the Komite Khilafat turned its attention to another invitation of Ibn Saud of Saudi Arabia who also wanted to hold a congress on the caliphate in Makkah in his effort to establish a new caliphate. Ibn Saud's invitation was discussed by the Indonesian Muslim leaders in the fourth Islamic Congress (held in Yogyakarta from August 21-27, 1925) and in the fifth Islamic Congress (held in Bandung on February 6, 1926). Before the Islamic Congress in Bandung was held, however, the reformist leaders had held a meeting in Cianjur, West Java, from January 8-10, 1926, in which they made a decision to send Tjokroaminoto of the Sarekat Islam and K.H. Mas Mansur of the Muhammadiyah to participate in the Congress on the caliphate which was to be held in Makkah.

Predictably, when the fifth Islamic Congress in Bandung was held, the Congress automatically confirmed the decision which had been made by the modernist Muslim leaders in the Cianjur meeting: Tjokroaminoto of the Sarekat Islam and K.H. Mas Mansur of the

\footnotetext{
${ }^{27}$ Ibid., p. 237.

28 Marjorie Kelly (ed.), Islam: The Religious and Political Life of a World Community (New York: Praeger, 1981), p. 199.
} 
Muhammadiyah were formally assigned to attend the Congress on the caliphate in Makkah. This decision made the traditionalist Muslim leaders, especially K.H. Abdul Wahab Hasbullah, deeply frustrated. Because of this frustration, he then proposed that the Congress request that the Wahhâbi ruler of Saudi Arabia maintain the teachings and practices of the four madhâhib which had been applied there before. The Congress rejected his proposal; consequently, Abdul Wahab increasingly felt alienated from the Congress.

In light of this unpleasant fact, Abdul Wahab and his three friends withdrew from the Komite Khilafat after being advised by K.H. Hasyim Asy'ari. K.H. Abdul Wahab Hasbullah then took the initiative by organizing the leading kyais and 'ulamâ' from several cities in Java. After a long and intensive negotiations and preparations, they agreed to establish their own committee, which later became known as the Komite Hijaz (Hijaz Committee). They planned to send their own delegates from this Committee to meet directly with King Ibn Saud to discuss religious matters which concerned them. This important movement of Abdul Wahab also became a starting point of the birth of the NU.

\section{The Early History of the NU}

As mentioned above, one of the prominent figures who took the initiative to establish the NU was K.H. Abdul Wahab Hasbullah. Abdul Wahab was born at Jombang, East Java, in 1888 and received his elementary Islamic teaching from his own father, Kyai Hasbullah, who ran the Pesantren ${ }^{29}$ of Tambakberas at Jombang. He then continued his study from one pesantren to another in East Java, such as the Pesantren of Pelangitan of Tuban, the Pesantren of Mojosari of Nganjuk, the Pesantren of Cepaka, the Pesantren of Tawangsari of Sepanjang, and the Pesantren of Branggahan of Kediri. He even reached a small island, Madura, east of Java, where he studied in the Pesantren of Kademangan, Bangkalan, for three years. ${ }^{30}$

29 Pesantren is a traditional Islamic educational institution. Students who study in the pesantren are called santris. According to a report made by the Indonesian Department of Religious Affairs, there were 4,195 pesantrens and 677,384 santris in Java in 1978. See Zamakhsyari Dhofier, Tradisi Pesantren: Studi tentang Pandangan Hidup Kyai (Jakarta: LP3ES, 1982), p. 43.

30 Aboebakar, Sejarah Hidup K.H.A.Wabid Hasyim dan Karangan Tersiar (Jakarta: Panitia Buku Peringatan Almarhum K.H. A. Wahid Hasyim 1957), p. 122. 
On the advice of his teacher, K.H. Khalil, the leader of the Pesantren of Kademangan, Abdul Wahab continued to study in the Pesantren of Tebuireng under the guidance of K.H. Hasyim Asy'ari for four years. Actually, Abdul Wahab and K.H. Hasyim Asy'ari were closely related, both having the same great grandfather. Because of his intellect and his family ties to his teacher, he was appointed to become the lurah pondok (director of the pesantren). At the age of twenty-seven, Abdul Wahab left Java for Makkah, where he studied Islam in the holy city for four years. In Makkah, he studied Islam under the guidance of six of the leading 'ulamā', Kyai Mahfudh at-Tarmisy, Kyai Mukhtaram, Shaykh Ahmad Khatib, Kyai Bakir, Kyai Asy'ari, and Shaykh Abdul Hamid. These six 'ulama' were Indonesians who had achieved positions as teachers in the Masjid al-Haram in Makkah at that time. ${ }^{31}$

By the end of World War II, Abdul Wahab returned from Makkah to Indonesia and stayed in Surabaya. With K.H. Mas Mansur, a modernist leader, Abdul Wahab collaborated to establish and supervise a madrasab (Islamic school) called Nahdlatul Watan (Renaissance of Fatherland). Abdul Wahab and Mas Mansur also established a discussion group called Taswirul Afkar (Beckoning to Reflection) which attracted many Muslim youths to study Islam. ${ }^{32}$ Apart from its positive results, the discussion group could not avoid touching the furu' questions. Mas Mansur then left Abdul Wahab when the former joined the Muhammadiyah in Yogyakarta. His long study, experience and activities enabled Abdul Wahab to emerge as an active and energetic young kyai with skillful leadership capabilities. He finally stepped forward to be an architect of the foundation of the NU.

After withdrawing from the Komite Khilafat, Abdul Wahab took the initiative and held meetings with leading kyais and influential 'ulamā' in Surabaya, Pasuruan, Jember, Semarang, Lasem, and Pati. In these meetings, they agreed to establish another committee which would send its own delegates to call on King Ibn Saud to discuss directly with him some urgent religious matters. Abdul Wahab felt that this was an alternative means of channeling the 'ulamā's aspirations after his proposals were rejected by the modernist leaders in the Islamic Congress in Bandung.

31 Ibid., p. 123.
32 Ibid., p. 125. 
To realize his dream, on January 31, 1926, K.H. Abdul Wahab invited the prominent 'ulamā' to his house in Surabaya to discuss what they had talked about in their meetings in several cities in Java. In addition to Abdul Wahab himself, the leading 'ulamā' who attended the meeting were, among others, K.H. Hasyim Asy'ari of the Pesantren of Tebuireng (Jombang), K.H. Bisri Syansuri of the Pesantren of Tambakberas (Jombang), K.H. Raden Asnawi of Kudus, Ma'mun of Lasem, Ridwan of Surabaya, H. Abdullah Ubaid of Surabaya, Alwi Abdul Aziz of Malang, H. Abdul Halim of Lewimunding (Cirebon), H. Doro Muntaha of Bangkalan (Madura), Dahlan Abdul Qahar of Kertosono, and H. Abdullah Faqih of Gresik. ${ }^{33}$

As a result of their meeting, these influential 'ulamā' made two important decisions which would later color the pages of Indonesian Islamic history. Firstly, they formally established the Komite Hijaz whose term would end when its delegates returned from Saudi Arabia to Indonesia. Secondly, they established an organization to act as an instrument for the 'ulama's' to guide the Islamic community in achieving the glory of Islam and of the Muslims. ${ }^{34}$ This organization, on the suggestion of K.H. Alwi Abdul Aziz, was called the NU. Thus, the NU was formally established in Surabaya, East Java, on January 31, 1926. The formation of its executive board, which became an important document in the historical development of the NU, was as follows:

Syuriah (Consultative Council):

Chairman : K.H. Hasyim Asy'ari

Vice-Chairman : K.H. Dahlan

Secretary I : K.H. Abdul Wahab Hasbullah

Secratary II : K.H. Abdul Halim

Assistants : K.H. Alwi Abdul Aziz

: K.H. Ridwan

: K.H. Said

: K.H. Bisri Syansuri

: K.H. Abdullah Ubaid

: K.H. Nakhrawi

: K.H. Amin

33 Ibid; p. 471.

${ }^{34}$ K.H. Saifuddin Zuhri, K.H. Abdul Wabab Hasbullab: Bapak dan Pendiri Nabdlatul Ulama (Jakarta: Yamunu,1972), p. 26. 


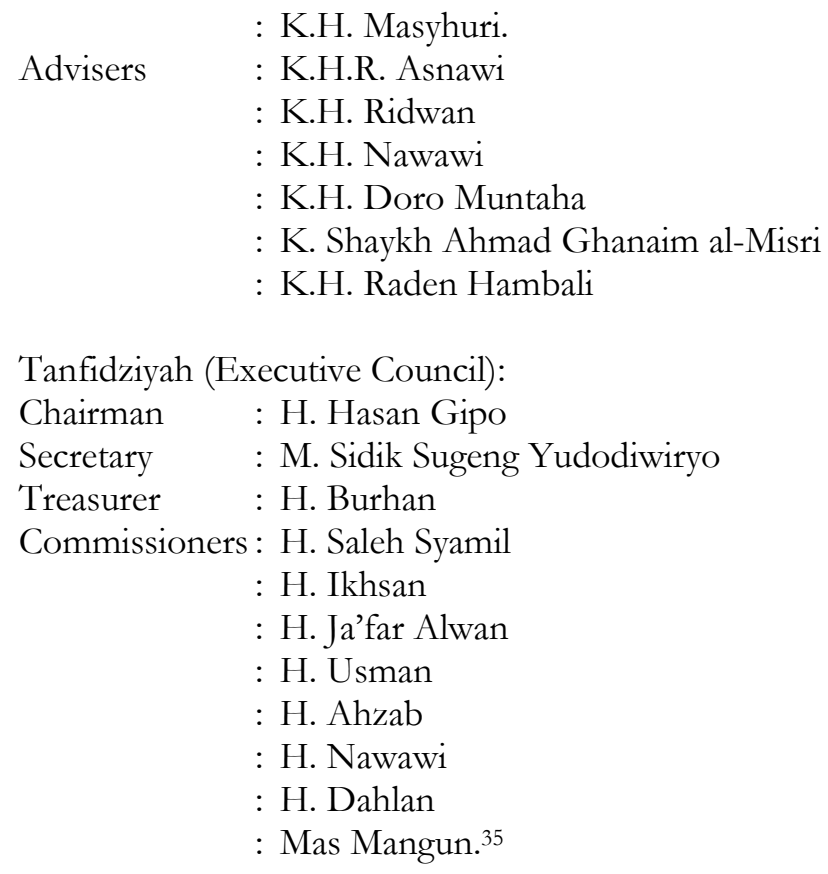

As we see above, the organizational structure of the NU was characterized by two councils, the Syuriah (Consultative Council) and the Tanfidziyah (Executive Council). The Syuriah consisted entirely of the 'ulama'-' who occupied the highest positions in the NU and served as its controllers, supervisors and policy makers. As for the Tanfidziyah, its members were to be the executors of day-to-day activities of the NU in accordance with the policies and decisions made by the Syuriah. Besides serving as supervisors and controllers of the organization, the Syuriah had a special task, that is, making fatwas in relation to religious questions. Its fatwâs were binding upon all members of the organization, including the Tanfidziyah. ${ }^{36}$

The goal of the NU, as mentioned in the second article of its Statute, was "to hold firmly one of the four madhāhib: the Hanafi, the Mālikìi, the Shäfīì, and the Hanbali school, and to carry out its program

\footnotetext{
35 Aboebakar, Sejarah Hidup, p. 472.

${ }^{36}$ K.H. Achmad Siddiq, Khittah Nabdliyah (Surabaya: Balai Buku, 1979), p. 15.
} 
which benefits Islam." ${ }^{37}$ To achieve this goal, the NU made efforts by: (a) Establishing the relationship among the 'ulamâ' who follow one of the four madhâhib mentioned in the second article above; (b)Examining books before they are used in teaching so that it can be known whether they are written by the group of ahl al-sunnah wa al-jamā'ah or by ahli bid'ah (innovators); (c) Preaching Islam based on one of the four madhâhib mentioned in the second article, using good methods. ${ }^{38}$

The existence of the NU was legally acknowledged by the colonial rule, the Netherlands Indies, on February 30, 1930, when it issued a letter of decision signed by De Algemeene Secretaris, G.R. Erdbrink. With the acknowledgement of the colonial rule, the NU could perform its programs and activities without being considered suspect. In other words, the NU was free to carry out its programs and activities as long as its movements and activities were not in the political arena. The Dutch colonial rule did not tolerate any movements or activities related to political affairs carried out by any organization. Any political activities performed by any organization were strictly banned by the Dutch colonial rule.

We still remember that the founding fathers of the NU planned to send their own delegates under their own committee, the Komite Hijaz. As mentioned above, Ibn Saud had adopted the Wahhābi teaching through which he made radical religious changes in the entire kingdom. Concerned with certain cases, the NU on behalf of the Indonesian 'ulamā' sent its representatives, K.H. Abdul Wahab Hasbullah and Shaykh Ahmad Ghanaim al-Misri, to call on the new King of Saudi Arabia on June 13, 1928. The two delegates, among others, requested that Ibn Saud continue to maintain the teachings and practices of the four madhāhib which had been applied before he came to power.

The King responded positively to their requests by promising to respect the teachings and practices of the four schools of Islamic law as had been taught by the teachers and 'ulamā' in the Masjid al-Haram in Makkah, Masjid al-Nabawi in Medina, and other places throughout

\footnotetext{
${ }^{37}$ See Solichin Salam, K.H. Hasyim Asy'ari: Ulama Besar Indonesia (Jakarta: Jaya Murni, 1963), p. 67.

${ }^{38}$ Ibid.
} 
the kingdom. ${ }^{39}$ The King even sent a letter to the NU in which he described the results of the discussion between him and the two delegates of the Komite Hijaz, hoping that other 'ulamā' of the NU would learn his response. In the view of the NU, its delegates were successful in carrying out their mission.

\section{Ulama, Pesantren and the Growth of the NU}

The name "Nahdlatul Ulama" was consciously chosen by the founding fathers of this organization. They chose the name "Nahdlatul Ulama" and not, for example, Nahdlatul Muslimin (Renaissance of Muslims) or Nahdlatul Ummah (Renaissance of the Islamic Community) in order to show how important and special the position of 'ulamā' was in the Nahdlatul Ulama. ${ }^{40}$ If other organizations relied, for their basic strength, on laborers, farmers, officers, and the like, the NU confidently determined that its main supporters and its central strength were the 'ulamâ', ${ }^{41}$ The position of 'ulama') as the pillars of the NU was based on two logical considerations. Firstly, the NU as a religious organization should derive its basic power from figures whose morality, religiousity and religious knowledge were guaranteed; and these figures were the 'ulamā'. Secondly, the 'ulamā' had authority among their santris and among their former santris who had spread out into many different areas. The 'ulamâ' also had direct influences among their community and their influences would be able to reach many rural areas. ${ }^{42}$

These influences made it possible for the NU to penetrate and maintain roots in rural Islam, especially in Javanese rural areas where a large percentage of the population of Indonesia lived. In other words, the NU, with its thousands of kyais and 'ulamā', gained its main supporters from the rural areas. At the village level, the kyais not only functioned as religious and spiritual leaders, but later, also as political leaders, precisely as Clifford Geertz has observed. ${ }^{43}$ In the NU, the

\footnotetext{
${ }^{39}$ Mohammad Sufyan Cholil and Masbuchin, Nabdlatul Ulama di Tengab-Tengab Rakyat dan Bangsa Indonesia (Kebumen: Daya Bhakti, 1967), p. 27.

40 Siddiq, Khittah, p. 13.

${ }^{41}$ Ibid.

42 Ibid., pp. 13-14.

43 See Clifford Geertz, "The Javanese Kijaji: The Changing Role of a Cultural Broker," Comparative Studies in Society and History, 2, 2 (January 1960), p. 247.
} 
titles of kyai and 'ulamâ' are not used arbitrarily; they indicate special qualities, such as fearing and obeying God, understanding and carrying out the message of the Prophet, being sensitive to the interests of the Muslim community, having good knowledge of religion, and devoting their knowledge to the God's purpose. ${ }^{44}$ It is not surprising if the "ulamā' of the NU always quote a Hadith which runs, "The "ulamā", are the inheritors of the prophets," a message which inspires them to do their duties. From this point of view, the NU placed them in the highest position to supervise and control its movements and activities.

The growth of the NU cannot be separated from the role of the kyais and 'ulamä', who had a far-reaching influence among the Muslim community. In a short time, the NU was accepted by Muslims both in Java and beyond. By 1930, the NU had six branches in West Java, twenty-one branches in Central Java, and eighteen branches in East Java. In the same year, a new branch was founded in Banjar, Martapura (Kalimantan) and it became the first branch of the NU beyond Java. A local organization called the Hidayah Islamiyah (Islamic Guidance) in Kalimantan merged with the NU in 1936. In its National Congress in Malang, East Java, held in 1937, seventy-one branches participated. ${ }^{45}$ When the Dutch were defeated by the Japanese in 1942, the NU had one hundred and twenty branches dispersed in many parts of Indonesia. 46

The main stronghold of the NU was Java, where thounsands from the pesantrens joined it. The reason the pesantrens joined the NU may be traced to the teachings of the NU and to the background of its founding fathers. The religious ideology of the NU was basically the same as the "value system" 47 which had been rooted in the pesantrens tradition for hundreds of years. Therefore, when the NU was founded and it declared its ideology to be that of ahlussunnah waljama'ah, the pesantrens readily joined it because of a strong religious tie which linked both. As a result, generally speaking, the NU and the pesantrens were interrelated, or even almost identical: the majority of the

\footnotetext{
${ }^{44}$ Siddiq, Khittah, p. 8.

${ }^{45}$ Noer, Modernist Muslim, pp. 231-232.

46 Usaha Penerbitan Ansor, Kumpulan Anggaran Dasar (Kudus: Menara, 1954), p. 5.

47 Sudjoko Prasojo et al, Profil Pesantren: Laporan Hasil Penelitian Pesantren Al-Falak dan Delapan Pesantren Lain di Bogor (Jakarta: LP3ES, 1974), p. 30.
} 
pesantrens belonged to the NU and the NU was deeply rooted in the tradition of the pesantrens.

In addition, the founding fathers of the NU itself had the educational backgrounds of the pesantrens and many of them had studied or graduated from the pesantrens. So, the NU was in fact born in the aspirations and traditions of the pesantrens. ${ }^{48}$ Two large and influential pesantrens which became the main bulwarks of the NU were the Pesantren of Tebuireng located at Jombang, East Java, led by K.H. Hasyim Asy'ari, and the Pesantren of Tambakberas which was also situated at Jombang and led by K.H. Abdul Wahab Hasbullah. Abdul Wahab led the Pesantren of Tambakberas after his father's death. From these two pesantrens came many of the leading figures of the NU who played an important role in the activities and the development of the NU.

As mentioned above, K.H. Hasyim Asy'ari and K.H. Abdul Wahab Hasbullah (also K.H. Bisri Syansuri) were among the founding fathers of the NU who made important efforts to develop their organization. Syansuri was related to Abdul Wahab through his marriage to Abdul Wahab's young sister and was also the father-in-law of K.H. Wahid Hasyim, son of K.H. Hasyim Asy'ari. K.H. Hasyim Asy'ari himself was born at Jombang in 1871. He received his elementary Islamic teaching from his own father, Kyai Asy'ari, a well known 'álim (religious scholar) who ran the Pesantren of Keras.

From the age of fifteen on, Hasyim Asy'ari studied in many pesantrens in East Java and Madura, such as the Pesantren of Wonokoco of Probolinggo, the Pesantren of Pelangitan, the Pesantren of Trenggalis, and others. While studying in the Pesantren of Kyai Ja'qub of Siwalan Panji of Sidoarjo, Hasyim Asy'ari married his teacher's daughter and, during the same year, he and his wife went to Makkah in order for him to deepen his knowledge of Islamic studies. After one year in the Holy City his wife died and he returned to Indonesia. After only three months stay in Java, he then went back to Makkah and spent seven years studying Islam. ${ }^{49}$

Hasyim Asy'ari focused on studying Hadith under the guidance of Shaykh Mahfudh at-Tarmisy, an Indonesian 'âlim who taught in the Masjid al-Haram at that time. After a long period of study, Hasyim

\footnotetext{
48 Zuhri, Sejarah Kebangkitan, p. 618.

${ }^{49}$ Akarhanaf, Kyai Hasyim Asy'ari: Bapak Ummat Islam Indonesia (Jombang: n.p., 1949), p. 29.
} 
Asy'ari was declared qualified to teach hadith by his teacher. Returning once again to Indonesia, he taught in his father's Pesantren of Keras, and then he established his own pesantren called the Pesantren of Tebuireng at Jombang, East Java, in 1899.50 Both his deep knowledge and far-reaching influence attracted some thousands of santris, especially from Java and Madura, to study Arabic and Islamic sciences under his guidance in his pesantren.

Recognizing his breadth of knowledge, the 'ulamā' throughout Java offered K.H. Hasyim Asy'ari an honorary title Hadratus Syeikh (The Great Teacher). Since the early 1990's his Pesantren of Tebuireng has become one of the most important centers of learning and has produced and supplied the pesantren leadership throughout Java and Madura in the twentieth century. ${ }^{51}$ There is no doubt that he and his pesantren played a significant role in maintaining the ideology of traditional Islam and in developing the wing of the NU by producing many kyais and 'ulamā', who became involved in the activities of the $\mathrm{NU}$, and helped to spread it throughout Java and Madura.

K.H. Hasyim Asy'ari served as the chairman of the Consultative Council of the NU for twenty-one years, from its creation in 1926 until his death in 1947. This indicates that his deep and broad knowledge and his great influence among the NU members enabled them to trust him to lead the NU. Under his leadership, the NU could carry out its program and activities in accordance with its ideology, vision and mission.

\section{Activities and Movements in the Late Dutch Period}

Consistent with its vision and mission, the NU always attempted to carry out its program in social and religious fields. It established more madrasas and improved their management, aided the foundation of the mosques, langgars (prayer houses) and pesantrens, and helped to provide for orphans and the poor. In 1929, the NU created an organization called the Ma'arif $\mathrm{NU}$ which served to co-ordinate and develop all educational institutions belonging to the NU. In 1937, the NU established a special body called Waqfiyah NU which was empowered with the purchase and administration of waqf lands on the

\footnotetext{
50 Ibid., p. 35.

51 Zamakhsyari Dhofier, Tradisi Pesantren: Studi tentang Pandangan Hidup Kyai (Jakarta: LP3ES, 1982), p. 99.
} 
basis of Islam and according to one of the four madhāhib. It also took an interest in the roles of young people and women. For that purpose, the NU established a youth organization called Persatuan Pemuda Nahdlatul Ulama (Youth Association of Nahdlatul Ulama) on December 13, 1932. This organization was transformed into Ansor Nahdlatul Ulama (Helper of the Nahdlatul Ulama) on April 24, 1934, and then this organization was transformed again into Gerakan Pemuda Ansor (Helper Youth Movement) on December 14, 1949.

The creation of a woman's organization in the NU was a long process which began in 1938. One year later, the idea of the foundation of Muslimat Nahdlatul Ulama (Muslim Women of the Nahdlatul Ulama) became widespread among NU circles. Finally, in March 1946, the formally established the Muslimat Nahdlatul Ulama, an organization for the women of the NU. In addition, between 19381939, the NU implemented a series of programs called Gerakan Khairu Ummah (The Best Umma Movement) by which it aimed at strengthening the spirit of economic co-operation among Indonesian people by increasing the nation's consciousness, and offering moral guidance based on three principles: honesty, faithfulness, and solidarity. .52

To spread its ideas and to communicate with its members, the NU published three magazines. The first magazine, called the Kemudi (The Rudder), was edited by Abdullah Ubaid. The Berita Nabdlatul Ulama (News of the Nahdlatul Ulama) was the second magazine, published bi-weekly and edited by K.H. Mahfudz Shiddiq. The third magazine, called Suara Nabdlatul Ulama (Voice of the Nahdlatul Ulama), was published monthly and edited by K.H. Abdul Wahab Hasbullah. The Suara Nabdlatul Ulama was published in three languages: Indonesian, Javanese, and Arabic. ${ }^{53}$

Not only did the NU pay attention to national affairs, but it also was concerned with international problems, particularly those affairs directly related to the interests of Islam and to the fundamental rights of the nation. When World War II broke out, the NU helped the neglected Indonesian students who were studying in Saudi Arabia to return home. Moreover, the NU fully supported the Palestinians and the Arabs who opposed the Balfour Declaration upon which the

\footnotetext{
${ }^{52}$ K.H. Idham Chalid, Mendaynng dalam Taufan (Jakarta: Api Islam, 1966), p. 57.

${ }^{53}$ Yusuf et al., Dinamika Kaum Santri, p. 34.
} 
Jewish state was built. The NU felt that the creation of the Jewish state, Israel, in the Palestinian fatherland was an encroachment upon the fundamental human rights of the Palestinians in particular and the Arab and Muslim world in general. ${ }^{54}$

Living under the pressure of the colonial rule, the NU was not able to ignore political questions, even though it was itself a socio-religious organization. It was under obligation to assume moral and political responsibility by opposing the Dutch policies which exploited and suppressed the Indonesian people and the Muslims. The NU openly banned the Muslim youths from entering the Dutch military service, prohibited the Muslims from supporting the Dutch army, and rejected the Dutch aid which was offered to the NU's madrasahs. ${ }^{55}$

In addition, the NU fully supported the GAPPI (Gabungan Partai Politik Indonesia, or Federation of Indonesian Political Parties) which demanded the establishment of the Majelis Rakyat Indonesia (Council of the Indonesian People) because the Volksraad benefited only the colonial rule. The NU further demanded that the Dutch revoke the Guru Ordonantie which contained unfair and discriminatory restrictions for the madrasas and the pesantrens. ${ }^{56}$ The oppressive Dutch policies against Indonesian Muslims caused the modernists and the traditionalists to unite. Both modernist and traditionalist Muslims opposed the Dutch policies which were injurious to the interests of Islam. Harry J. Benda depicted this new approach by saying that "the opposition to external force narrowed the gap between the reformists and orthodox to the point where Muhammadiyah and the NU could jointly sponsor the creation of a new Islamic federation, the MIAI (Majelisul Islamil A'la Indonesia, or Great Islamic Council of Indonesia), which was set up in Surabaya in September 1937." 57

The MIAI was led by K.H. Wahid Hasyim of the NU; other Muslim leaders who sat in the committee were Sukiman, Wondoamiseno, Kyai Mas Mansur, K.H. Mahfudz Shiddiq, Umar Hubeis, and others. The appointment of K.H. Wahid Hasyim as the chairman of the MIAI was a momentous development for the NU

\footnotetext{
${ }^{54}$ Cholil and Masbuchin, Nabdlatul Ulama, p. 27.

55 Ibid., p. 28.

56 Ibid., p. 27.

57 Harry J. Benda, The Crescent and the Rising Sun: Indonesian Islam Under the Japanese Occupation 1942-1945 (Dordrecht: Foris Publication Holland, 1983), p. 90.
} 
since it had not been possible in previous times. Through Wahid Hasyim, the NU was entrusted with the leadership of this new Islamic federation by the modernist Muslim leaders. This indicates the NU's increasing maturity and prestige in the Islamic movement in Indonesia. It also demonstrates the NU's increasing strength and foreshadows its important role in the later development of the Indonesian Islamic movement.

\section{The Japanese Occupation}

In 1941 the Pacific War between the Allies and Japan broke out, leading to the defeat of the Dutch by the Japanese. Consequently, the former left Indonesia and the latter began to establish power in Indonesia. Shortly after that, the Japanese military rule took action by disbanding all social and political organizations, including the NU.58 During this critical time, the NU limited its activities to administering its madrasas and pesantrens, and preserving Islamic preaching. While it is true that the $\mathrm{NU}$, as an organization could be dissolved, its socioreligious activities which were deeply rooted in the pesantrens scattered in many parts of country sides were impossible to stop. Not only was the formal organization of the NU disbanded, but the chairman of its Consultative Council, K.H. Hasyim Asy'ari, and the chairman of its Executive Council, K.H. Mahfudz Shiddiq, were arrested by the Japanese military authorities as well. These two leading figures of the NU were accused by the Japanese military authorities of organizing anti-Japanese movement and of encouraging the 'ulamâ' in particular and the Muslim community in general to oppose the Japanese. ${ }^{59}$

During this critical period, K.H. Abdul Wahab Hasbullah, together with K.H. Wahid Hasyim and K.H. Nahrawi Tahir, took over the leadership of the NU and provided the organization with a continued leadership. K.H. Hasyim Asy'ari was first jailed at Jombang, then he was moved to a prison in Mojokerto and later he was sent to jail at Bubutan, Surabaya, East Java. ${ }^{60}$ K.H. Abdul Wahab Hasbullah and other leaders of the NU took the initiative and demanded that the

58 Usaha Penerbitan Ansor, Kumpulan, p. 5. Later, the Japanese military rule permitted the Nahdlatul Ulama to re-establish itself.

59 Zuhri, Sejarah Kebangkitan, p. 632.

${ }^{60}$ Salam, K.H. Hasyim Asy'ari, p. 49. See also Akarhanaf, K.H. Hasyim Asy'ari, pp. 48-49. 
Japanese military authorities release the two former leaders from jail. After some five months in jail, K.H. Hasyim Asy'ari was freed, as was K.H. Mahfudz Shiddiq a short time later. K.H. Mahfudz Shiddiq's health gradually deteriorated and he finally died on January 1, 1944 in Jember, East Java. It was he who had transformed the NU into a modern organization. He was regarded by other leaders of the NU as an organizer and innovator who contributed his energies and ideas to the progress of the NU while serving as the chairman of its Executive Council between 1937-1942.

K.H. Hasyim Asy'ari was one of the most influential 'ulamā' whom the Japanese military authorities feared. When the Japanese ordered the Indonesian people to perform the saikeirei (bowing the body toward the rising sun to honor the Emperor Tenno Heika), K.H. Hasyim Asy'ari firmly declared his rejection of this practice. He issued a fatw $\bar{a}$ (legal opinion) saying that the saikeirei was shirk (associating others with God) and he stressed that it was prohibited by Islam. ${ }^{61}$ It was, perhaps, one of the contributing factors that led the Japanese military authorities to capture and silence him by putting him in jail.

On February 18, 1944, a revolt broke out in the village of Singaparna, near Tasikmalaya, West Java. This rebellion was led by Kyai Zainal Mustafa, an influential orthodox teacher and loyal member of the NU in that area. ${ }^{62}$ The uprising occurred when the Japanese military authorities "commenced with a ruthlessly enforced requisitioning of rice." 63 In Benda's words, Mustafa's rebellion was an expression of Islamic grass-roots power which "threatened the country's infidel rulers." 64 The insurrection was quickly quelled and Mustafa himself was officially declared insane by the Japanese military authorities. However, in an attempt to appease the Muslim community, they did not blame other Islamic leaders as a whole for what had happened.

Unlike the Netherlands Indies administration, which had not given Muslim leaders a chance to take part in politics, the Japanese military government opened the door for Muslims to experience and participate in governmental politics and military training. In the early

\footnotetext{
${ }^{61}$ Yusuf et al., Dinamika Kaum Santri, p. 36.

${ }^{62}$ Benda, The Crescent, p. 160.

${ }^{63}$ Ibid.

${ }^{64}$ Ibid.
} 
months of their occupation, the Japanese created the Shumubu (Office of Religious Affairs) in the capital city, and various branches of the Shumubu, called the Shumuka, were opened throughout the archipelago. ${ }^{65}$ The Shumubu was similar to the Office for Native Affairs during the Dutch colonial period, but it later became an office which tackled affairs that had been previously administered by the Department of Internal Affairs, the Department of Justice, and the Department of Education and Public Worship. ${ }^{66}$

Initially, the Shumubu was headed by Colonel Hore, a Japanese. He was succeeded by Professor Husein Djajadiningrat, who was later replaced by K.H. Hasyim Asy'ari of the NU. Because Hasyim Asy'ari was busy with running his pesantren at Jombang, his day-to-day tasks in the Shumubu were carried out by his son, K.H. Wahid Hasyim, together with K.H.A. Kahar Muzakkir, who also became a leading figure in the Shumubu. Another advantage gained by Indonesian Muslims during the Japanese occupation was the foundation of the Hizbullah (Army of God), in late 1944, which was a kind of military unit for Muslim youths. Initially, according to K.H. Masykur, members of the Hizbullah came from the NU circle, but later it was opened to all Muslims. ${ }^{67}$ The Hizbullah was led by K.H. Zainul Arifin of the NU, and he was accompanied by other Muslim leaders, such as Anwar Tjokroaminoto, Mohammad Roem, Prawoto Mangkusasmito, and K.H. Masykur. ${ }^{68}$

Besides the Hizbullah, the Muslim leaders also created the Sabilillah (God's Path), a military unit for the 'ulamâ' led by K.H. Masykur of the NU. In practice, according to Masykur, the Sabilillah formed the main body of the Hizbullah. ${ }^{69}$ Through the Hizbullah and the Sabilillah, the Muslims of Indonesia learned to use modern weapons under the training of their leaders, something which would have been impossible under the Dutch occupation. As far as the Japanese were concerned, this military training was part of the so-

\footnotetext{
${ }^{65}$ B. J. Boland, The Struggle of Islam in Modern Indonesia (The Hague: Martinus Nijhoff, 1971), pp. 9-10.

${ }^{66} \mathrm{Ibid}$.

${ }^{67}$ See Serial Media Dakwah, No. 62 (August, 1979), pp. 18-19.

68 Zuhri, Sejarah Kebangkitan, pp. 633-634.

${ }^{69}$ See Serial Media Dakwah, p. 19.
} 
called "Nippon's Islamic grass-roots policy," 70 which was designed to aid Japan in defeating the Allies.

From the developments mentioned above, we can see that some leading figures of the NU played a significant role in the leadership of the Shumubu, the Hizbullah and the Sabilillah. Moreover, from these developments, we may conclude that the NU's influence and strength came to be considered an essential part of the Islamic leadership in Indonesia. In fact, when a new Islamic federation called the Masyumi (Majelis Syuro Muslimin Indonesia, or Consultative Council of Indonesian Muslims) was established in 1943, virtually all Muslim leaders, including the modernist leaders, agreed to appoint K.H. Hasyim Asy'ari of the NU as its president, while his son, K.H. Wahid Hasyim, was elected as vice-chairman of the Masyumi. K.H. Wahid Hasyim served as his father's representative in the day-to-day operations of the Masyumi, since K.H. Hasyim Asy'ari was devoted to teaching in his Pesantren of Tebuireng. Other Muslim leaders who sat in the committee included Ki Bagus Hadikusumo of the Muhammadiyah, K.H.A. Halim of the Persatuan Ummat Islam (Muslim Unity), and K.H. Ahmad Sanusi of the Perbimpunan Ummat Islam Indonesia (Indonesian Muslim Association). ${ }^{71}$

These were some significant factors that made the NU become increasingly important in the development of Indonesian Islamic movements. As we have seen from the descriptions above, from 1906 until the creation of the MIAI in 1937, Islamic leadership had always been in the hands of reformist leaders, particularly the Sarekat Islam. The influence of the Sarekat Islam, however, gradually declined after the death of its noted leader, H.O.S. Tjokroaminoto, in 1934. The Sarekat Islam leaders were involved in internal disputes and conflicts which caused Sukiman Wirjosandjojo to leave the group and

\footnotetext{
${ }^{70}$ Benda, The Crescent, p. 134.

71 Zuhri, Sejarah Kebangkitan, p. 633. In the Muslim Congress held in Yogyakarta from November 7-8, 1945, the Masyumi was transformed into a political party. Indonesian Muslim leaders agreed unanimously that the Masyumi was to be the only political party through which the Muslims would struggle to achieve their political ideals. However, because of internal conflicts, the Sarekat Islam and the Nahdlatul Ulama left the Masyumi, the former in 1947 and the latter in 1952. The Sarekat Islam and the Nahdlatul Ulama declared themselves as independent political parties which were separate from the Masyumi. For further discussion see Ahmad Syafi'i Maarif, Islam dan Masalah Kenegaraan: Studi tentang Percaturan dalam Konstituante (Jakarta: LP3ES, 1985), pp. 115-121.
} 
established his own party called the Partai Islam Indonesia (Indonesian Islamic Party) in 1938. He was joined in this endeavor by Muhammad Natsir, Abdul Kahar Muzakkir and other modernist leaders. ${ }^{72}$

Meanwhile, H. Agus Salim quit the Sarekat Islam and founded his own party called the Penyadar (Realizer) after a dispute occurred between him and Abikusno Tjokrosujoso, Tjokroaminoto's successor as chairman of the Sarekat Islam. ${ }^{73}$ Out of this tragic situation, the NU emerged as an impressive force and it continued to grow stronger because of the unity, integrity and solidarity among its leaders and between its leaders and members. The charismatic, influential and strong leadership of the ' $\mathrm{u} 1 \mathrm{ama}$ ' in the NU was one of the most important factors which enabled it to play an important role in the development of Indonesian Islamic leadership following the establishment of the MIAI in 1937. The NU, founded in 1926, took eleven years to win a significant role in the Indonesian Islamic movements.

The appointment of some important leaders of the NU to top posts in such organizations as the Shumubu, the Hizbullah, the Sabilillah and the Masyumi gives a clear indication that the NU was able to play a significant national role in the Islamic movement in Indonesia. Another important national role for the NU came on April 9, 1945, when the BPUPKI (Badan Penyelidik Usaha-Usaha Persiapan Kemerdekaan Indonesia, or the Investigating Committee for the Preparation of Indonesian Independence) was established in fulfillment of the Japanese promise, made by Prime Minister Koiso on September 9, 1944, to give independence to the Indonesian people. ${ }^{74}$

Sixty-eight members sat in the committee of the BPUPKI, two of whom (K.H. Wahid Hasyim and K.H. Masykur) came from the NU circle. An influential member of the BPUPKI, Wahid Hasyim was appointed to be one of the nine members of the sub-committee of the BPUPKI which formulated the preamble of the 1945 Constitution of the Indonesian state. One of the main agenda of the BPUPKI was to debate whether Islam or Pancasila to be used as the basis of a free state of Indonesia. Soekarno, a leading figure of the secular nationalists,

\footnotetext{
${ }^{72}$ Maarif, Islam dan Masalah, p. 91.

73 Ibid.

${ }^{74}$ M.A. Aziz, Japan's Colonialism and Indonesia (The Hague: Martinus Nijhoff, 1955), p. 228.
} 
proposed Pancasila ${ }^{75}$ as the basis of Indonesian State. Soekarno's original concept of Pancasila run: (1) nationalism; (2) internationalism or humanitarianism; (3) delibaration or democracy; (4) social walfare; (5) belief in God.

After a long and heated debate between Muslim and secular nationalist leaders concerning whether the basis of the state was to be Pancasila or Islam, the two fractions achieved a political compromise in the form of the creation of the Piagam Jakarta (Jakarta Charter) on June 22, 1945 in which they agreed upon Pancasila as the basis of state. The formulation of Pancasila in the Jakarta Charter run: (1) Belief in One God with the obligation to practice the shari'ah for its adherents; (2) Just and civilized humanity (3) the unity of Indonesian; (4) Democracy which is guided by the inner wisdom in unanimity arising out of deliberation amongst representatives; (5) Social justice for the whole of the people of Indonesia.

K.H. Wahid Hasyim was one of the nine members who signed the Jakarta Charter. According to Dhofier, the appointment of K.H. Wahid Hasyim as a member of the sub-committee of the BPUPKI indicated his intellectual capacity and served to bridge the differences between the traditionalist and modernist Muslims and the secular nationalist leaders. ${ }^{76}$ In a further political development, Pancasila in the Jakarta Charter was reformulated by deleting the Islamic words "with the obligation to practice the shari'ah for its adherents" (dengan kewajiban menjalankan syariat Islam bagi pemeluknya). This new formulation of Pancasila was agreed by Muslim leaders (including K.H. Wahid Hasyim of the NU) and this new formulation of Pancasila has been permanently employed as the basis of the state up to the present.

The involvement of K.H. Wahid Hasyim in the creation of the Jakarta Charter, in the process of preparation for independence and in the creation of the Indonesian state increasingly expanded the importance of the NU in the national political development. At this stage of development, the NU participated equally with other national movements in the political struggle to achieve Indonesian

\footnotetext{
75 Pancasila is a Sanskrit word, meaning five principles (from panca, five, and sila, principle). The creator of Pancasila was Sukarno, the first president of Indonesia. The use of the term Pancasila was suggested by Muhammad Yamin, author and ardent nationalist.

${ }^{76}$ See Dhofier, Tradisi Pesantren, p. 106, and p. 4.
} 
independence. In a certain respect, it can be said that the emergence of the NU on the national surface coincided with the rise of K.H. Wahid Hasyim as a national leader. In Benda's eyes, he was "perhaps the most prominent representative of Indonesian Islam at the close of the Japanese era." 77

As mentioned above, K.H. Wahid Hasyim was a son of K.H. Hasyim Asy'ari and was born at Jombang, East Java, in 1914. He inherited his father's influence and charisma and, more importantly, he matured in his own intellectual capacity and became a skillful leader. Between 1932 and 1933, he studied Islam in Makkah and he was active as a leader of the NU after 1938. When the chairman of the Executive Council of the NU, K.H. Mahfudz Shiddiq, died in 1944, Wahid Hasyim succeeded him. Following this, Wahid Hasyim not only emerged as a leading figure in the NU circle, but also at the national level. He was appointed state minister when President Sukarno established his first cabinet in September 1945, and from 1949 until 1952 he served as minister of religious affairs, contributing greatly to the progress of the Department of Religious Affairs which he headed. ${ }^{78}$

\section{The Independence War}

On August 6 and 9, 1945, the United States dropped its atom bombs in Hiroshima and Nagasaki which resulted in the surrender of the Japanese to the Allies on August 15, 1945. Two days after that, August 17, 1945, Sukarno and Mohammad Hatta proclaimed Indonesian independence in Jakarta on behalf of the Indonesian people. Shortly thereafter, the British army landed in Jakarta as representatives of victorious Allies, particularly the Dutch, who intended to restore their colonial rule. The Indonesian people reacted strongly against the presence of the British and battles broke out in many cities. The Indonesian people fought fiercely to defend their newly declared independence.

The largest confrontation, in which all Indonesian forces, including the kyais and 'ulamā', joined Commander Sudirman and Bung Tomo to fight staunchly against the enemy's army, took place in Surabaya,

\footnotetext{
77 Benda, The Crescent, p. 189.

${ }^{78}$ Dhofier, Tradisi Pesantren, p. 107. Wahid Hasyim succeeded his father K.H. Hasyim Asy'ari as the leader of the Pesantren of Tebuireng after his father's death in 1947. Wahid Hasyim died in 1953 of a car accident.
} 
East Java, on November 10, 1945. K.H. Wahid Hasyim and K.H. Zainul Arifin, who led the Hizbullah, advanced to the front line to fight together with other Indonesian militia men. ${ }^{79}$ In this critical situation, the NU took action by calling together all its consuls throughout Java and Madura and holding a meeting in Surabaya, where it issued the Resolusi Jihad (Holy War Resolution) on November 22, 1945.

The Resolution stated that: (1) Indonesian independence, which was proclaimed on August 17, 1945, must be defended, (2) The Republic of Indonesia, as the only legal government, must be defended and secured, (3) The enemies of the Republic of Indonesia, particularly the Dutch in conjunction with the Allies' army (the British) who were handling the Japanese war captives, are intent upon using this political and military chance to recolonize Indonesia, (4) The Muslims, especially the NU, are obliged to take up arms against the Dutch and their allies who want to recolonize Indonesia, and (5) This obligation is a Jihad (Holy War) and is fardu 'ain (an individual obligation) for every Muslim who stayed within the radius of 94 kilometers. ${ }^{80}$ Those who stayed outside that distance are obliged to help their brothers in Islam who have stayed within the radius of 94 kilometers mentioned above. ${ }^{81}$

With the proclamation of the Resolusi Jihad by the NU, Indonesian Muslims sprang to the defense of the nation's independence. Many Muslim youths joined the Hizbullah and the Sabilillah fighters (led by K.H. Masykur), risking their lives to defend Indonesian independence. K.H. Abdul Wahab Hasbullah led the Mujahidin (Freedom Fighters), organized the kyais and 'ulamā', and collaborated with the Hizbullah and the Sabilillah to combat the enemy's troops. ${ }^{82}$ In a certain respect, the Resolusi Jihad of the NU inspired and encouraged many kyais and 'ulamâ' in particular and

\footnotetext{
${ }^{79}$ See Cholil and Masbuchin, Nabdlatul Ulama, p. 43.

80 The Nahdlatul Ulama has determined that 94 kilometres is the minimum distance required to be able to perform salat jama' (to combine two prayers, for example, the noon prayer and the afternoon prayer, and perform them at the same time -- either at noon or in the afternoon) and salat qas r (to shorten the four-rak'a prayer to a two-rak'a prayer). According to Islamic law, salat jama' and salat qassr are allowed when Muslims are travelling or for various reasons accepted by the shari'a.

81 Yusuf et al., Dinamika Kaum Santri, p. 38.

${ }^{82}$ See Zuhri, Sejarah Kebangkitan, p. 637.
} 
Indonesian Muslims in general to become involved in the battles being waged in many cities, such as those in Plagan, Ambarawa, Semarang, Bandung, and other important cities. ${ }^{83}$ The slogans voiced by the Muslims during this period were "Love of the country is part of the iman (faith)" and "Live honorably or die as a martyr to Islam". These slogans strongly encouraged the Muslims to devote their lives to defending Indonesian independence.

Until 1949, the Indonesia's struggles to defend its independence continued to flare up. In their attempts to recolonize Indonesia, the Dutch launched two police actions. The first police action was initiated by the Dutch in July, 1947 and the second in December, 1948. By means of these two actions, they succeeded in re-occupying many parts of Indonesia. Faced with the modern weapons of the Dutch forces, Indonesian fighters mobilized an all-out effort to resist the Dutch through guerilla warfare. The situation became more and more critical and many Indonesian fighters died in the fighting which ensued. During this critical period, K.H. Hasyim Asy'ari of the NU incited the Muslims to continue to fight against the Dutch who colonized Indonesia for a long time. Hasyim Asy'ari issued two important fatwâs, calling, in the first, for a jihād (holy war) against the Dutch, and, in the second, prohibiting Indonesian Muslims from performing the hajj by using the Dutch ships. K.H. Hasyim Asy'ari's campaign was largely successful due to his strong influence, particularly in East Java and Central Java. ${ }^{84}$

The role of K.H. Hasyim Asy'ari in the independence war was very important. His Pesantren of Tebuireng was used as a headquarters for the Hizbullah and the Sabilillah fighters. He gave not only material support but also moral support to the Muslim fighters who visited him before they left for the front lines. General Sudirman and Bung Tomo even visited him to secure his religious advice and his fatwas which inspired and strengthened their spirits in leading the Indonesian fighters against the Dutch. ${ }^{85}$ In firing the moral spirit of the Indonesian fighters through his fatwâs, Hasyim Asy'ari always kept abreast of the military developments in the front lines. When he heard that the city of Malang, the Eastern front line of Indonesian defense, had fallen into

\footnotetext{
83 Aboebakar, Sejarah Hidup, p. 478.

${ }^{84}$ See Dhofier, Tradisi Pesanren, p. 99.

${ }^{85}$ See Salam, K.H. Hasyim Asy'ari, p. 49.
} 
the hands of enemy, he was deeply distressed, and two delegates of General Sudirman and Bung Tomo who visited him to inform him of the fall of Malang were not able to talk to him. Hasyim Asy'ari died soon afterwards on July 25, 1947. Like other Indonesian fighters, he truly loved independence and his country. Finally, Indonesia secured its freedom and sovereignty on December 27, 1949, after a series of negotiations between the Dutch and the leaders of the new republic.

Like other national movements in Indonesia, the NU, and the kyais and 'ulamā' who formed its membership, felt obliged to struggle to achieve and defend Indonesian independence. This obligation was motivated by feelings of responsibility for their nation and their religion, which were, of course, inseparable in the view of the NU. In the national context, the struggles of the NU were stimulated by its national consciousness and sense of responsibility. In the Islamic context, the struggles of the NU were encouraged by its religious consciousness and sense of responsibility. These two kinds of consciousness and responsibility reinforced each other and became a dynamic power which enabled the Muslims in general and the NU in particular to devote their lives to the struggle for achieving and defending the Indonesian independence. It is not surprising for the $\mathrm{NU}$ that the Indonesian government later named its two leading figures, K.H. Hasyim Asy'ari and K.H. Wahid Hasyim, as National Independence Heroes because of their great contributions, dedication and devotion during the Independence War between 1945-1949.86

\section{Conclusion}

From the descriptions above, it can be concluded that the NU was born in the atmosphere and the culture of pesantren where the doctrine of 'traditional Islam' has been deeply rooted in preserved. The role of K.H. Abdul Wahab Hasbullah (the leader of the Pesantren of Tambakberas, Jombang, East Java) and K.H. Hasyim Asy'ari (the founder of the Pesantren of Tebuireng, Jombang, East Java) were very significant in the process of the establishment of the NU at that time. Because of their important and widespread influences among traditional Muslim people, especially in rural areas, these two leading kyais succeded in preserving and developing the NU. As a result, many other kyais, especially in Java and Madura, joined or established

\footnotetext{
${ }^{86}$ See Dhofier, Tradisi Pesantren, p. 126.
} 
branches of the NU in their regions. The establishment of branches of the NU not only took place in Java and Madura at that time, but also outside Java. By this means, the NU grew strongly not only in Java, but also in other regoins in Indonesia. The symbiotical relations among kiyais (ulama), santris and pesantrens contributed greatly to the significant growth and development of the NU in many regions in Indonesia.

The NU -through its leading figure K.H. Wahid Hasyim (son of K.H. Hasyim Asy'ari) - played an important role in the reformulation of Pancasila as the basis of the Indonesian State so that Pancasila was accepted by all political streams, religious groups and social organizations in Indonesia. In addition, the NU -together with other nationalist movements- also contributed greatly to the process of preparing for the nation independence; in building of the Indonesian state; and in the war to defend Indonesian independence. Many kyais of the NU took up arms and were involved in the struggle to free Indonesia from the colonial rule. As a result, Indonesia became a new independent and free state. Both K.H. Hasyim Asy'ari and his son K.H. Wahid Hasyim were appointed by the government as National Independence Heroes because of their important role, dedication and contribution to the Indonesian State.

Despite the fact that the NU at that time was completely or purely a socio-religious organization (not a political organization), it felt obliged morally and nationally to struggle against the Dutch colonial rule and taking part in the war to defend the Indonesian independence. For the NU, nationalism and patriotism became part of iman (religion). Therefore, for the NU, nationalism and patriotism or nationality and religiousity could not be separated from the khittah (the spirit of struggle) because the two elements were closely integrated in its fighting spirit and became a prime mover in its struggle to devote itself to achieving the interests of the nation and state.[]

\section{Bibliography}

\section{Books and Articles}

Abbas, K. H. Siradjuddin. I'tiqad Ablussunnah Waljama'ah. Jakarta: Pustaka Tarbiyah, 1981.

Abdullah, Taufiq (ed.). Islam di Indonesia. Jakarta: Tintamas, 1974.

Aboebakar, H. Sejarah Hidup K.H. A. Wabid Hasyim dan Karangan 
Tersiar. Jakarta: Panitia Buku Peringatan Almarhum K.H. A. Wahid Hasyim, 1957.

Adisaputro, M. Mundhir. "Peranan Ummat Islam di Zaman Jepang". Serial Media Dakwah. (n.d.), pp. 17-19.

Adnan, A. Basit. Ke-NU-an. Yogyakarta: Pengurus Wilayah Nahdlatul Ulama, 1981.

Akarhanaf. Kyai Hasyim Asy'ari: Bapak Ummat Islam Indonesia. Jombang: n.p., 1949.

Ali, A. Mukti. Alam Pikiran Islam Modern di Indonesia. Yogyakarta: Yayasan Nida, 1964.

Amin, Osman. Muhammad Abduh. Trans. Charles Wendell. Washington: American Council of Learned Societies, 1953.

Antonious, George. The Arab Awakening: The Story of the Arab National Movement. Beirut: Librairie Du Liban, 1969.

Asqalani, Ibn Hajar, Al. Fath a1-Bâri, vol.V. Cairo: Mustafa al-Halaby, 1378/1958.

Asy'ari, K.H. Hasyim. Al-Durarul Muntasyirah. Kudus: Penerbit Menara, 1940.

. At-Tarbiyatul Wajibat. Surabaya: Ashabah al-Naktabah alNihayah al-Qubra, 1973.

-------. At-Tibyan fin-Nabyi'an Mugatha'atil Arham. n.p., n.d.

--------. Qonun Asasi Nabdlatul Ulama. Kudus: Penerbit Menara, 1971.

. Risalab Mubimmah. Surabaya: Nahdlatul Ulama, n.d.

Atjeh, Aboebakar. Ablussunnah Waljama'ah: Filsafat Perbandingan Hukum dalam Islam. Jakarta: Yayasan Baitul Mal, 1969.

Aziz, M.A. Japan's Colonialism and Indonesia. The Hague: Martinus Nijhoff, 1955.

Baihâqi, Al. A1-Sunân a1-Qubrâ, vol. II. India: Matba'a Uthmaniyya, $1346 / 1927$.

Benda, Harry J. The Crescent and the Rising Sun: Indonesian Islam Under the Japanese Occupation 1942-1945. Dordrecht: Foris Publication Holland, 1983.

Boland, B.J. The Struggle of Islam in Modern Indonesia. The Hague: Martinus Nijhoff, 1971. 
Chalid, Idham. Mendayung dalam Taufan. Jakarta: Api Islam, 1966.

Cholil, Muhammad Sufyan and Masbuchin. Nabdlatul Ulama di TengahTengah Rakyat dan Bangsa Indonesia. Kutoarjo: Daya Bhakti, 1967.

Cole, Juan R.I. and Nikki R. Keddie (eds.). Shi'ism and Social Protest. New Haven: Yale University Press, 1986.

Coulson, N.J. A History of Islamic Law. Edinburgh: University of Edinburgh Press, 1984.

Dhofier, Zamakhsyari. Tradisi Pesantren: Studi tentang Pandangan Hidup Kyai. Jakarta: LP3ES, 1982.

Effendi, Djohan and Ismed Natsir (eds.). Pergolakan Pemikiran Islam: Catatan Harian Abmad Wabib. Jakarta: LP3ES, 1982.

Enayat, Hamid. Modern Islamic Political Thought. Austin: University of Texas Press, 1982.

Fadhali, Amak. NU dan Aqidahnya. Semarang: Toha Putra, 1969.

Geertz, Clifford. "The Javanese Kijaji: The Changing Role of a Cultural Broker". Comparative Studies in Society and History, 11/2 (January 1960): pp. 228-249.

-------. Islam Observed: Religious Development in Morocco and Indonesia. Chicago: The University of Chicago Press, 1971.

-------. The Religion of Java. Chicago: The University of Chicago Press, 1971.

Gibb, H.A.R. Modern Trends in Islam. New York: Octagon Books, 1981.

-------. Mohammedanism: An Historical Survey. London: Oxford University Press, 1970.

Goldziher, Ignaz. Introduction to Islamic Theology and Law. Trans. Andras and Ruth Hamori. Princeton: Princeton University Press, 1981.

Hadikusuma, Djarnawi. Muhammadiyah: Ahlussunnah Waljama'ah? Yogyakarta: Siaran, n.d.

Hamka. Pengaruh Mohammad Abduh di Indonesia. Jakarta: Tintamas, 1961.

Hitti, Philip K. History of the Arabs. London: The Macmillan Press, Ltd., 1980.

Holt, P.M. et al (eds.). The Cambridge History of Islam, vol. 2A. Cambridge: Cambridge University Press, 1987.

Hourani, Albert. Arabic Thought in the Liberal Age 1798-1939. 
Cambridge: Cambridge University Press, 1983.

Jalil, K. Abdul. Tubfah al-Asfya. Semarang: Toha Putra, 1963.

Kelly, Marjorie (ed.). Islam: The Religious and Political Life of a World Community. New York: Praeger, 1984.

Khadduri, Majid, trans. Islamic Jurisprudence: Shafii's Risala. Baltimore: The Johns Hopkins Press, 1961.

Ma'sum, Sjihabuddin. Sejarah Pertumbuhan Nahdlatul Ulama. Yogyakarta: Sumbangsih, 1968.

Maarif, Ahmad Syafii. Islam dan Masalah Kenegaraan: Studi tentang Percaturan dalam Konstituante. Jakarta: LP3ES, 1985.

Mansoer, Tolchah. Pokok-Pokok Ablussunnab Waljama'ah dan Kepemimpinannya. Yogyakarta: Sumbangsih, 1984.

Musthafa, K.H. Bisyri. Risalah Ablussunnah Waljama'ah. Kudus: Yayasan al-Ibriz Menara Kudus, 1967.

Nakamura, Mitsuo. The Radical Traditionalism of the Nahdlatul Ulama: A Personal Account of the 26 th National Congress, June 1979, Semarang. Trans. Al-Ghazi Usman. Surakarta: Hapsara, 1982.

Noer, Deliar. Partai Islam di Pentas Nasional. Jakarta: Grafiti Press, 1987.

--------. The Modernist Muslim Movement in Indonesia 1900-1942. Kuala Lumpur: Oxford University Press, 1973.

Pengurus Besar Nahdlatul Ulama. Nabdlatul Ulama Kembali ke Khittah 1926. Bandung: Penerbit Risalah, 1985.

Pickthall, Mohammad Marmaduke. The Meaning of the Glorious Koran: An Explanatory Translation. New York: Mentor, n.d.

Prasodjo, Sudjoko et al. Profil Pesantren: Laporan Hasil Penelitian Pesantren Al-Falak dan Delapan Pesantren Lain di Bogor. Jakarta: LP3ES, 1982.

Raharjo, M. Dawam (ed.). Pesantren dan Pembaharuan. Jakarta: LP3ES, 1985.

Rahman, Fazlur. Islam. Second edition. Chicago: The University of Chicago Press, 1979.

Roff, William R. (ed.). Islam and the Political Economy of Meaning: Comparative Studies of Muslim Discourse. Los Angeles: University of California Press, 1987. 
Salam, Junus. Riwayat Hidup K.H.A. Dablan: Amal dan Perjuangannya. Jakarta: Depot Pengajaran Muhammadiyah, 1968.

Salam, Solichin. K.H. Hasyim Asy'ari: Ulama Besar Indonesia. Jakarta: Jaya Murni, 1963.

Siddiq, K.H. Achmad. Khittah Nahdliyyah. Surabaya: Balai Buku, 1979.

Steinberg, David Joel (ed.). In Search of Southeast Asia: A Modern History. Honolulu: University of Hawaii Press, 1986

Usaha Penerbitan Ansor. Kumpulan Anggaran Dasar. Kudus: Menara, 1954.

Yusuf, Slamet Effendy et al. Dinamika Kaum Santri: Menelusuri Jejak dan Pergolakan Internal NU. Jakarta: CV Rajawali, 1983.

Ziemek, Manfred. Pesantren Islamische Bildung in Sozialen Wandel. Trans. Butche B. Soendjojo. Jakarta: P3M, 1986.

Zuhri, K.H. Saifuddin. Menghidupkan Nilai-Nilai Ablussunnah Waljama'ah dalam Praktek. Jakarta: Pucuk Pimpinan IPNU, 1976.

-------. Sejarah Kebangkitan Islam dan Perkembangannya di Indonesia. Bandung: PT Al-Ma'arif, 1979.

-------. K.H. Abdul Wabab Hasbullab: Bapak dan Pendiri Nabdlatul Ulama. Jakarta: Yamunu, 1972. 